\title{
Changes in Phenolics and Protein Content during Seed Dermination of Carthamus tinctorius L.
}

\author{
Laurentiu Mihai PALADE ${ }^{1,2}$, Carmen MANOLE 2 , Andreea DOBRE ${ }^{1,2}$, Laura MARIN $^{2}$, Diana GOLEA 2 , and \\ Catalina TUDORA ${ }^{2}$ \\ ${ }^{1}$ Department of Biotechnology. University of Agronomic Sciences and Veterinary Medicine, Bucharest, \\ Romania. \\ ${ }^{2}$ Department of Biotechnologies. National Institute of Research and Development for Biological \\ Sciences, Bucharest, Romania. \\ * corresponding author: manolecarmen2000@yahoo.com
}

Bulletin USAMV series Agriculture 72(1)/2015

Print ISSN 1843-5246; Electronic ISSN 1843-5386

DOI 10.15835/buasvmcn-agr: 10678

\begin{abstract}
Semintele de Carthamus tinctorius L., sunt recunoscute pentru potentialul lor energetic. Capacitatea lor germinativa alaturi de alte caracteristici ce tin de variabilitatea genetica au fost putin studiate. Astfel, in acest sens in cadrul acestei lucrari ne-am propus sa studiem mobilizarea rezervelor din semintele soiului de sofranel Brigea, pe parcursul procesului de germinatie, in vederea stabilirii punctelor de cumul maxim ai caracteristicilor analizate.

The used biological material consists of safflower seeds in different germination stages (seeds - S I, seedlings-SII, plantlets-SIII, plantswithoutroots-SIV, roots-SV). The extractswereobtained using phosphatebuffer pH 7. Plant extracts were subjected to the following analysis: spectrophotometrically determination of total protein content, phenolic and flavonoid content.

With regard to the total protein content of the analyzed extracts, the highest values were and $9.1 \mathrm{~g} / 100 \mathrm{~g} \mathrm{FW}$, recorded in S III stage. Also, the total flavonoid content during the germination stages ranged between $0.08 \mathrm{~g}$ and $0.21 \mathrm{~g}$ rutin equivalent $(\mathrm{RE}) / 100 \mathrm{~g} F \mathrm{~F}$. The highest value of phenols during seed germination was performed in the S III with $1.08 \mathrm{~g}$ gallic acid equivalent (GAE).

The obtained results show that the bioaccumulation of phenolics and protein content in safflower during seed germination is influenced by the germination stage, impunand investigatii viitoare asupra procesului de germinatie si a posibilitatii de valorificare in domenii conexe.
\end{abstract}

Keywords: germination seeds, in vitro, safflower extracts.

\section{INTRODUCTION}

Carthamus tinctorius L., commonly known as safflower, is a member of the Compositae family. Cultivated mainly for its seed, safflower plant with high seed oil contents is considered to be one of the good options as feed-stock alternative material for biodiesel production (Mushtaq, 2014). Also, there are studies regarding the components of safflower, its seeds containing numerous polyphenolic compounds, flavonoids and serotonins (Young, 2009).

\section{AIMS AND OBJECTIVES}

The objective of this study was to highlight the variation of protein accumulation and total phenolic content during seed germination, and to determine the stage of maximum accumulation of these characteristics for future use in human or animal nutrition.

\section{MATERIALS AND METHODS}

The biologic material was represented by the seeds of safflower (Chartamus tinctorius L.) in different stages of germination.

The seeds were obtained from plants cultivated in the field in the Giurgiu - Ruse region, after the cultivation of the Bridgea cultivar. These were subjected to a surface sterilization protocol using mercuric chloride $1 \%$ for 8 minutes, 
Tab. 1. Changes in seed reserves in different stages of germination

\begin{tabular}{ccccc} 
No.crt & Germination stages & $\begin{array}{c}\text { Total protein content } \\
\text { g/100g FW }\end{array}$ & $\begin{array}{c}\text { Total phenolic content } \\
\text { g GAE/100g FW }\end{array}$ & $\begin{array}{c}\text { Total flavonoid content } \\
\text { (g RE/100g FW) }\end{array}$ \\
\hline 1 & SI & $1.45 \pm 0.41$ & $1.23 \pm 0.05$ & $0.21 \pm 0.01$ \\
2 & S II & $4.67 \pm 0.33$ & $0.80 \pm 0.02$ & $0.16 \pm 0.01$ \\
3 & S III & $9.10 \pm 1.41$ & $1.08 \pm 0.05$ & $0.2 \pm 0.01$ \\
4 & S IV & $4.31 \pm 0.38$ & $0.52 \pm 0.01$ & $0.08 \pm 0.00$ \\
5 & S V & $4.55 \pm 0.21$ & $0.35 \pm 0.01$ & $0.11 \pm 0.00$ \\
\hline
\end{tabular}

followed by rinsing 5 times with double distilled water. The seeds germinated in glass tubes on filter paper with distilled water, at $25^{\circ} \mathrm{C}$ at a $12 \mathrm{~h}$ light/ dark photoperiod. After germination, the seeds were removed, and the fresh plant material was subjected to extraction. The analyzed germination stages were: seeds (S I), seedlings (S II), plantlets (S III), plants without roots (S IV), roots (S V).

The plant extracts were obtined using phosphate buffer $\mathrm{pH} 7$ and were subjected to subsequent analyses. Thus, there were determined the following: polyphenol content using the FolinCiocâlteu method (Singleton, 1999), flavonoid content using a method adapted after Zhishen (1999), and total protein content by the Bradford method. The results were expressed as $\mathrm{g} / 100 \mathrm{~g}$ fresh material (FW).

\section{RESULTS AND DISCUSSION}

The obtained results (Table 1) showed that the maximum accumulation of the biochemical parameters analysed is in the S III germination stage. With regard to the protein content, that our results for protein contents appear to be like other published results, who showed higher than those calculated for whole seeds.

The bioaccumulation of phenols during seed germination was performed in the following order: S III $>$ S I $>$ S II $>$ S IV > SV.

\section{CONCLUSION}

The obtained results show that the bioaccumulation of phenolics and protein content in safflower during seed germination is influenced by the germination stage, varying from one state to the other, without having to follow a defined path.

Acknowledgements. This work was supported by research contract MIS-ETC 146-2(3i)-3.1$1 / 2011$

\section{REFERENCES}

1. Mushtaq A, Lee Keat T, Shazia S, Inam Ullah K, Ahmad Abdullah Z , Muhammad Z \& Fayyaz-ul H (2014). Optimization of Biodiesel Production from Carthamus tinctorius L. Cv.Thori 78: A Novel Cultivar of Safflower. Crop International Journal of Green Energy 11:1-32.

2. Singleton VL, Orthofer R, and Lamuela-Raventos RM (1999). Analysis of total phenols and other oxidation substrates and antioxidants by means of Folin - Ciocâlteu reagent. Methods in Enzymology 299:152-178.

3. Zhishen J, Mengcheng T, and Jianming W (1999). The determination of flavonoid contents in mulberry and their scavenging effects on superoxide radicals, Food Chemistry 64:555-559.

4. Yuhua B, Ping L, Chenghua $\mathrm{H}$, Chunyue $\mathrm{Y}$, Minggang C, Fa H, Dan Y, and Lijun W (2012). Hydroxysafflor Yellow A (HSYA) from Flowers of Carthamus tinctorius L. and Its Vasodilatation Effects on Pulmonary Artery, Molecules, 17:14918-14927. 